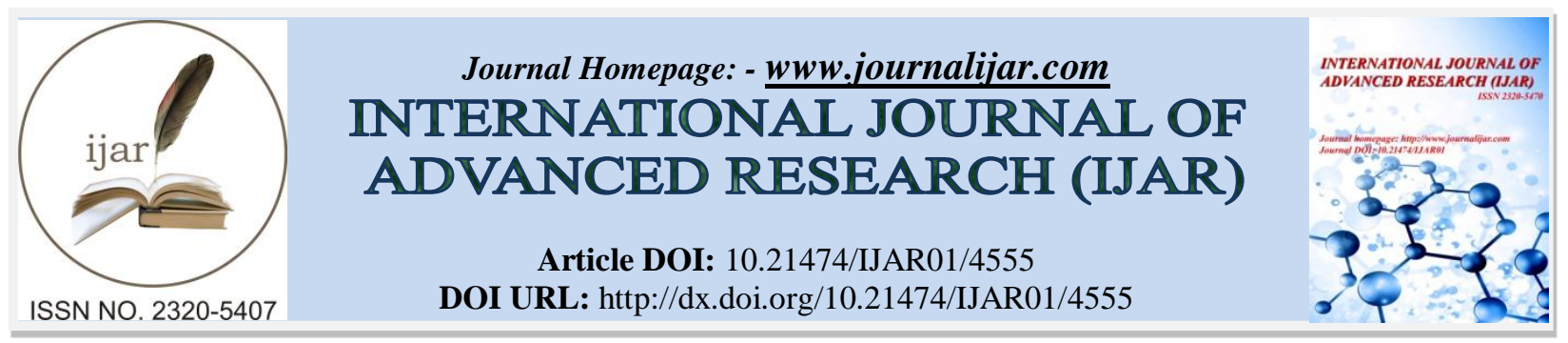

RESEARCH ARTICLE

\title{
AN EMPIRICAL APPROACH TO THE EFFECT OF NON-OIL EXPORT ON NIGERIAN ECONOMY.
}

Michael Chukwunaekwu Nwafor.

Department of Accounting and Finance Godfrey Okoye University, Enugu.

\section{Manuscript Info}

Manuscript History

Received: 21 April 2017

Final Accepted: 23 May 2017

Published: June 2017

\section{Abstract}

This research work focused on the effect of Non-oil Export on Nigerian Economy. Using Ordinary least squares regression technique, two hypotheses were formulated and tested using data spanning from 2004 to 2013. Results showed that non-oil exports have positive significant impact on economic growth of Nigeria and that non-oil exports have positive and significant impact on the value of Nigerian currency. It was recommended however that the export base of Nigeria should be diversified to favour the non-oil sectors to help reduce sector marginalization as this will also help cushion the effect of price shocks in the international oil (crude oil) market.

Copy Right, IJAR, 2017,. All rights reserved.

\section{Introduction:-}

Exportation is a prerequisite for a country to improve its revenue base and usher in economic growth and development. Hence, it is crucial for economic advancement and this has formed the idea of export-led growth. This is the bedrock of any country seeking international worth. Foreign trade serves as a medium through which foreign capital flows into a country: this increases the earnings of the country as foreign capital boosts the economicactivity in a country which enhances growth and development. It also improves the value of a country's currency over time as export has been a traditional and most sustainable way a country waxes strong externally. Exportation by a country also helps attain a favourable balance of trade and balance of payment position for the exporting country provided its exports reasonably exceed its imports.

In a country like Nigeria where there is an increased capital flight due to macroeconomic instability, foreign capital is very much needed in order to increase productivity and consequently economic growth. The Nigerian economy has been an economy that relies on over-exploitation of one mineral resource as major source of revenue. For instance, at independence, the major export commodity was cocoa and the leading sector in the economy was the agricultural sector but today, the major export commodity is crude oil and the leading sector is now the petroleum sector. This has not allowed for balanced growth in the economy as some sectors have been allowed to grow while growth has been impeded in others and this has made the country remain a developing country.

Nigeria, since the 1970s has been a mono-cultural economy relying heavily on oil as its major source of revenue. The implication is that the dynamics of the economy is at the mercy of the price of oil, which for the most part, has been volatile (Enoma and Mustafa, 2011) and as of today has fallen to the point of causing global economic shakeups (mostly for countries like Nigeria whose major source of revenue is oil).

The over-dependency on oil heightened the need and call for the diversification of Nigerian economy from oil towards the direction of non-oil export trade so as to ensure that other sectors of the economy grow to the level of 
the oil sector. Advocates of this increased proportion of non-oil export argue that the non-oil trade has great potentials to complement in boosting Nigerian economy to the desired growth and development. Onwualu (2012) maintains that the value chain approach to agriculture has the potentials to open up the economy and generate various activities which are capable of creating jobs and enhancing industrialization and thus makes the non-oil subsector to hold the aces for future Nigerian sustainable economic growth. This is not to say that only the agricultural sector is to be put to mind when referring to non-oil sector. The Governor of Kaduna mentioned in a newspaper that Kaduna has more gold reserves than South Africa (although not verified by fact). The problem is Nigeria don't explore natural resources, we stumble into it. I believe, that deposited in the land of Nigeria, there are more natural resources that we are yet to discover. The moment Nigeria explore them and make use of them to enhance the wellbeing of the people and the country at large so that in the nearest future, we can start talking about helping other African Nations. Being a giant of Africa is not a title, it is a call to serve other African Nations - helping them realize a sustainable economy.

The Nigerian governments on their part have shown efforts over the years to grow the non-oil export trade by establishing supportive policies. Some of these policies with varying degrees of successes include but not restricted to: protectionism policy in the mode of import substitution policy of industrialization in the 1960s; trade liberalization policy (this took the form of Structural Adjustment Programme (SAP)) of the mid 1980s and export promotion policy of 1990s which was executed through intensified policy support to Small and Medium Scale Enterprises (SMEs) to enhance productivity and subsequently, export of local products.

There are other scholars, who are skeptical about the possibility of the non-oil sector contributing significantly to economic growth forgetting that Nigeria have in time pasts depended on this neglected sector. They argue that since the economy is currently largely oil-dependent, what should have made sense is to increase the local content and technology transfer profile of the sector and ensure effective management of the proceeds from oil for development. Nigeria as a country doesn't need anything to survive this harsh economic times than to boost exportation at all cost. If Nigeria like some countries of the world (i.e. Arab where the ratio of their export to import trade is over 2:1) boosts exportation and discourages importation not just by increasing import duties, but by banning the importation of some products we can do without, a milestone will be achieved. Invigorating the non-oil sector so that its volume exportable goods can top that of oilis the only move that can sustain our economy, pumping billions of dollars into the money market can only give us a temporary improvement in the value of our currency, other important economic variables like inflation will not change. Expanding the export-base by investing into locally manufactured goods will give us a lasting economic peace and any government concentrating on a single means of revenue for survival is preparing a future economic doom because the stance of price irregularities will affect such economy as it shouldn't have. Hence the well-known adage of 'don't put your eggs in one basket' is a traditional economic wisdom countries like Nigeria should imbibe.

We look forward to a nation whose all sectors contribute significantly to economic output, hence the drive to pursue this study.

\section{Objectives of the Study:-}

The researcher aims, at the end of this study, to achieve the following objectives:

1. To determine the extent to which the non-oil exports have helped to enhance the economic progress of Nigeria between 2004 and 2013.

2. To determine the extent non-oil exports affects the value of Nigerian currency 2004 and 2013.

\section{Hypotheses of the Study:-}

1. Non-oil exports have no positive significant impact on economic growth of Nigeria.

2. Non-oil exports have no positive and significant impact on the value of Nigerian currency.

\section{Empirical Review:-}

Ozurumba and Chigbu (2013) examined the effect of non-oil export credits on economic growth in Nigeria for the period 1984 to 2009. The study utilized a multiple linear regression technique to examine the effect of non-oil export credits on economic growth and Granger causality tests to determine the direction of causation between the variables. The study observed that banks credits for agriculture and forestry, mining and construction, and nominal effective exchange rates have negative impact on non-oil gross domestic product in Nigeria while banks credits for merchandise export, import and domestic trade, public utilities and services impacted positively on non-oil gross 
domestic product.The causality estimate revealed unidirectional causality from GDP to public utilities and services, and agriculture and forestry. The study recommended the need for a sustainable programme towards the diversification of the economy by developing the non-oil sector, which will in turn enhance the revenue accruing to the country.

Riman et al (2013) examined the nexus among oil revenue shock, non-oil export and industrial output in Nigeria for the period 1970 to 2010. The study employed Vector Autoregressive (VAR) model and co-integration technique to examine the long run relationship, while the Vector Error Correction Model (VECM) was used to analyze the shortrun behaviour of the variables. The Johansen co-integration estimate showed that a long run behaviour exist among oil revenue shock, non-oil export, policy/regime shift and industrial output in Nigeria. The VECM estimate showed that the speed at which industrial output converges towards long-run equilibrium after experiencing shock from oil revenue was very slow. The long run estimate showed that oil revenue shock and policy/regime shift had negative impact on industrial output and non-oil export. The impulse response function and variance decomposition analysis suggested that the major drivers of industrial development in Nigeria are non-oil export, regime shift and oil revenue. The study recommended the diversification of the economy from crude oil export and ensuring a stable government that will endure long enough to sustain industrial and other economic policies.

Ningi (2013) examined the effect of banks financing on non-oil exports in Nigeria. The study employed questionnaires which were distributed to 120 non-oil exporting firms. Tools used for data analysis and hypotheses testing included: mean and standard deviation, and multiple regression. The multiple regression estimate indicated that non-oil exports financing by banks significantly accounts for slightly $16 \%$ of variance in non-oil exports performance, similarly the beta coefficient revealed that firm' perception of banks attitude to risk of financing nonoil exports had the highest beta value followed by cost of bank finance. Also the study observed that exchange rate fluctuation and access to credit facility had insignificant relationships with non-oil exports performance in Nigeria.

Raheem and Busari (2013) examined the impact of non-oil export on economic growth in Nigeria for the period 1970 to 2010. The study employed Simultaneous Equation Model (SEM) and a single equation model. The growth equation in the SEM showed that non-oil export and agricultural performance negatively impacted on economic growth, while the single equation model showed that the industrial sector performance and population growth are good determinant of economic growth. The study recommended the need for increase in government participation and patronage as well as creating investment friendly environment for investors in the sector.

Onodugo et al. (2013) examined the impact of non-oil export on economic growth in Nigeria for the period 1981 to 2012. Employing Endogenous Growth Model (EGM), the study observed a very weak and infinitesimal impact of non-oil export on economic growth in Nigeria. Edame and Efefiom (2013) descriptively analyzed the trends of oil revenue and oil export as it relates to other potential economic variables required for the transformation of the Nigerian economy. The study concluded that the Nigerian economy has not reaped the benefits of oil resource due to high level of mismanagement of her resources. Thus, the study recommended the maximization the huge revenue derived from oil export by channelling oil revenue towards the development of other critical sectors of the economy e.g. the agricultural and manufacturing sectors.

Olurankinse and Fatukasi (2012) examined the impact of non-oil export on economic growth in Nigerian. The study employed an ordinary least square (OLS) technique and observed that non-oil export has positive impact on the economic growth. The study recommended the need to increase production in both agricultural and manufacturing sectors to ensure product availability for both local and export purposes. The study also recommended an urgent completion of the export processing zones to promote the establishment of export oriented firms that will produce solely for export market. Enoma and Isedu (2011) examined the impact of financial sector reforms on non- oil export in Nigeria from 1986 to 2009. The study found a positive relationship between financial sector reforms and non-oil export in Nigeria. The study recommended that financial sector reforms should be improved upon and sustained by the monetary in order to fully optimise the gains.

\section{Research Methodology:-}

The research design employed by the researcher is ex post-facto research which aims at determining or establishing or measuring the relationship between one variable and another or the impact of one variable on another (Onwumere, 2009). 
The nature of data for the analysis of this study is secondary and data for this study is gotten from the Central Bank of Nigeria Statistical Bulletin, 2013.

A regression model has been employed, the essence of regression is to use a mathematical equation to express the nature of the relationship existing between variables and ultimately to use this equation to predict the value of one variable given a specific value of the other variable (Ugbam, 2001). This research work uses a two-model regression to capture the interaction between: non-oil exports and economic growth; and non-oil exports and the value of Nigerian currency. The basic aim of the regression model in this study is to investigate empirically the extent to which the predictor variable explains the variation in dependent variable (i.e. to establish the influence non-oil exports has over economic growth in Nigeria and the value of Nigerian currency). The model will be estimated using the coefficients of the independent variable and its level of significance. This test provides an empirical platform in drawing generalization for this study. The variable to be predicted is called the dependent variable while the variable whose value will be used in the prediction is called the independent variable (Ugbam, 2001).

In analyzing data, the simple regression model will be employed which is represented as:

$\mathrm{Y}=\mathrm{b}_{0}+\mathrm{b}_{1} \mathrm{X}+\mu$.

Where

$\mathrm{Y}=$ the variable we are trying to predict

$\mathrm{b}_{0}=$ the intercept

$\mathrm{b}_{1}=$ the slope

$\mathrm{X}=$ the variable we are using to predict $\mathrm{Y}$

$\mu=$ the error term

The intercept $\left(\mathrm{b}_{0}\right)$ is the value of the dependent variable when the independent variable is equal to zero while the slope of the regression line $\left(\mathrm{b}_{1}\right)$ represents the rate of change in $\mathrm{Y}$ as $\mathrm{X}$ changes. Because $\mathrm{Y}$ is dependent on $\mathrm{X}$, the slope describes the predicted values of $\mathrm{Y}$ given $\mathrm{X}$.

The above model can thus be applied in this study as:

$\mathrm{GDP}=\mathrm{b}_{0}+\mathrm{b}_{1} \mathrm{NOE}+\mu$.

Where

GDP - Gross Domestic Product (proxy for Economic growth) \{Dependent Variable

NOE - Non-Oil Exports (Independent Variable)

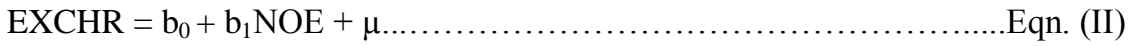

Where

EXCHR - Exchange Rate (Dependent Variable)

NOE - Non-Oil Exports (Independent/Explanatory variable)

\section{Techniques of Data Analysis:-}

Techniques of data analysis employed by the researcher is the ordinary least square method using the Statistical Package for Social Sciences (SPSS) Version 22. The researcher chose this method because it minimizes the squares of the residuals. The formulas for obtaining the estimates of the beta coefficients, standard errors, etc. are all based on this principle. The aim of using this method is to minimize the error in our prediction of the dependent variable, and by minimizing the residuals, error will be minimized. By using the "squares" the researcher is precluding the problem of signs thereby giving positive and negative prediction errors the same importance.

Data Presentation:-

Table 3.1:- Gross Domestic Product, Non-oil Exports and Exchange rate of Nigeria from 2004 to 2013.

\begin{tabular}{|c|c|c|c|c|c|c|}
\hline \multirow[t]{2}{*}{ YEAR } & \multicolumn{2}{|l|}{ GDP } & \multicolumn{2}{|l|}{ NOE } & \multicolumn{2}{|l|}{ EXCHR } \\
\hline & Amount ('Billion) & \% Change & Amount ('Billion) & \% Change & $\begin{array}{c}\text { Amount } \\
\text { (NGN/Dollars) }\end{array}$ & \% Change \\
\hline 2004 & $11,411.07$ & 0 & $4,602.80$ & 0 & 132.85 & 0 \\
\hline 2005 & $14,610.88$ & 28.04 & $7,246.50$ & 57.44 & 129 & -2.90 \\
\hline 2006 & $18,564.59$ & 27.06 & $7,324.70$ & 1.08 & 127 & -1.55 \\
\hline 2007 & $20,657.32$ & 11.27 & $8,309.80$ & 13.45 & 116.8 & -8.03 \\
\hline 2008 & $24,296.33$ & 17.62 & $10,114.70$ & 21.72 & 131.25 & 12.37 \\
\hline 2009 & $24,794.24$ & 2.05 & $8,402.20$ & -16.93 & 148.1 & 12.84 \\
\hline 2010 & $54,204.80$ & 118.62 & $11,706.70$ & 39.33 & 148.8127 & 0.48 \\
\hline 2011 & $63,258.58$ & 16.70 & $14,822.60$ & 26.62 & 156.7 & 5.30 \\
\hline
\end{tabular}




\begin{tabular}{|r|r|r|r|r|r|r|}
\hline 2012 & $71,186.53$ & 12.53 & $14,736.10$ & -0.58 & 155.92 & -0.50 \\
\hline 2013 & 80222.13 & 12.69 & $14,840.70$ & 0.71 & 155.7375 & -0.12 \\
\hline
\end{tabular}

Source:Computed by the Researcher from CBN Statistical Bulletin, 2013

The above table shows that in 2004, the Gross domestic product stood at 11,411.07, while total volume of non-oil exports was 4,602.80 and exchange rate was at 132.85. 2005 witnessed a slight increase in GDP from its value in 2004 to N14, 610.88 billion representing a $28.04 \%$ increase; NOE increased also by $57.44 \%$ while there was a fall in the price of dollar over naira by $2.90 \%$ showing that there was improvement in naira from $132.85 / \mathrm{USD}$ to N129/USD.

In 2006, the value of GDP witnessed a slight decrease by $27.06 \%$, NOE also fell by $1.08 \%$ while EXCHR improved by $1.55 \% .2007$ closed with an $11.27 \%$ decline in GDP, NOE triggered up by $13.45 \%$ and EXCHR also improved by $8.03 \%$. In 2008 , the value of GDP witnessed a huge increase by $17.62 \%$, NOE also increased in the same sequence by $21.72 \%$ and EXCHR declined by $12.37 \%$.

There was a decline in GDP in Nigeria by $2.05 \%$ in 2009 , NOE also declined by $116.93 \%$ while EXCHR witnessed a slight decline by $12.84 \%$. in 2010, there was a double-effect increase by $118.62 \%$ in GDP, this may be attributed to the slight decline the GDP witnessed the previous year by $2.05 \%$, NOE witnessed also experienced a boom by $39.33 \%$ and EXCHR witnessed a slight fall by 0.48\%. In 2011, the GDP of Nigeria witnessed a 16.70 decline, the NOE witnessed also witnessed a huge decline by $26.62 \%$ and the EXCHR experienced a slight decline by $5.30 \%$. 2012 folded leaving the GDP of Nigeria to a $12.53 \%$ decline, the NOE also witnessed a decline slightly while EXCHR improved insignificantly by $0.5 \%$. Finally, in 2013 , GDP improved by $12.69 \%$, NOE also insignificantly improved by $.071 \%$ while EXCHR followed suit by $0.12 \%$

Figure 3.1:- Gross Domestic Product.

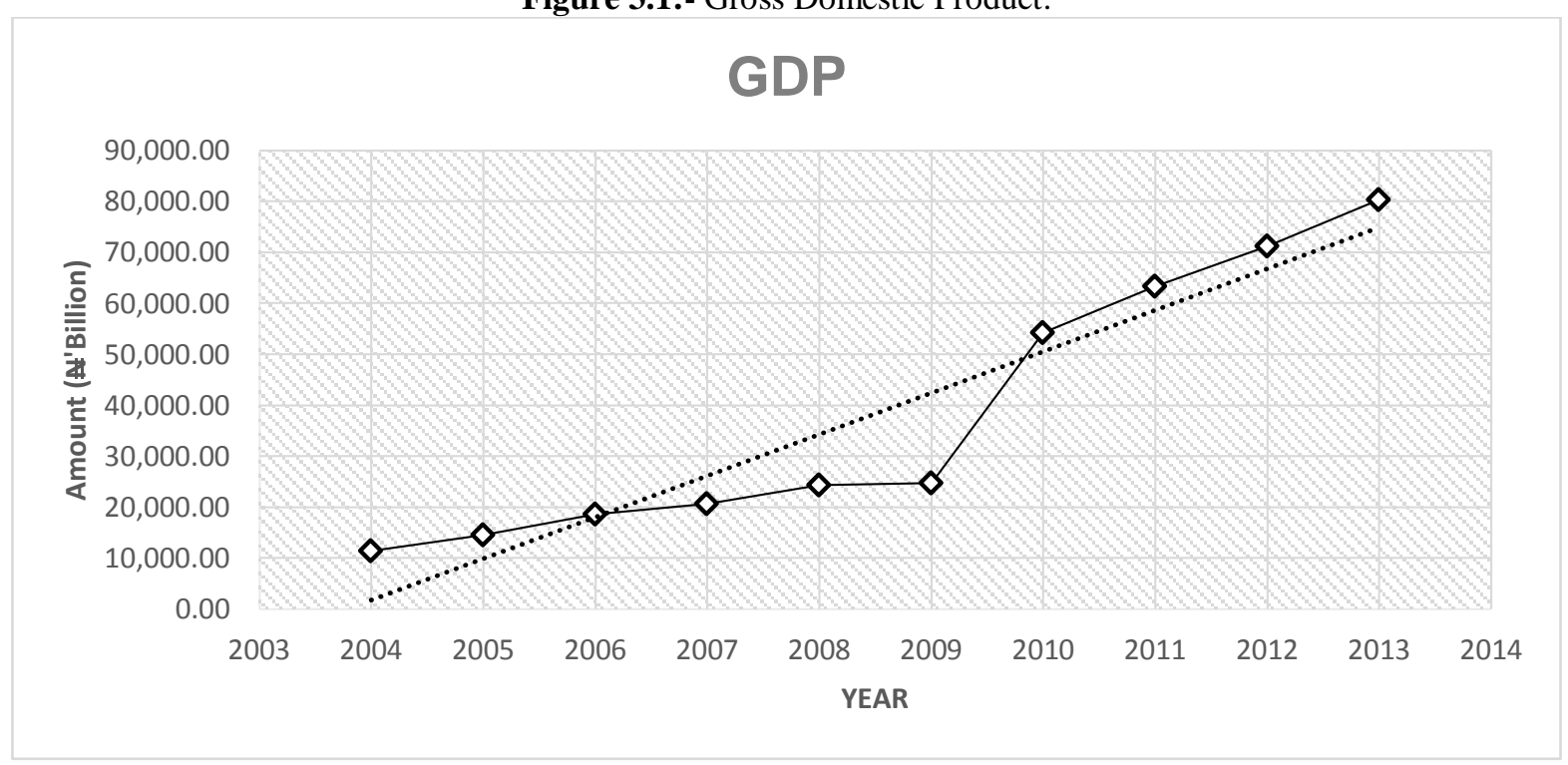


Figure 3.2:- Total Value of Non-Oil Export

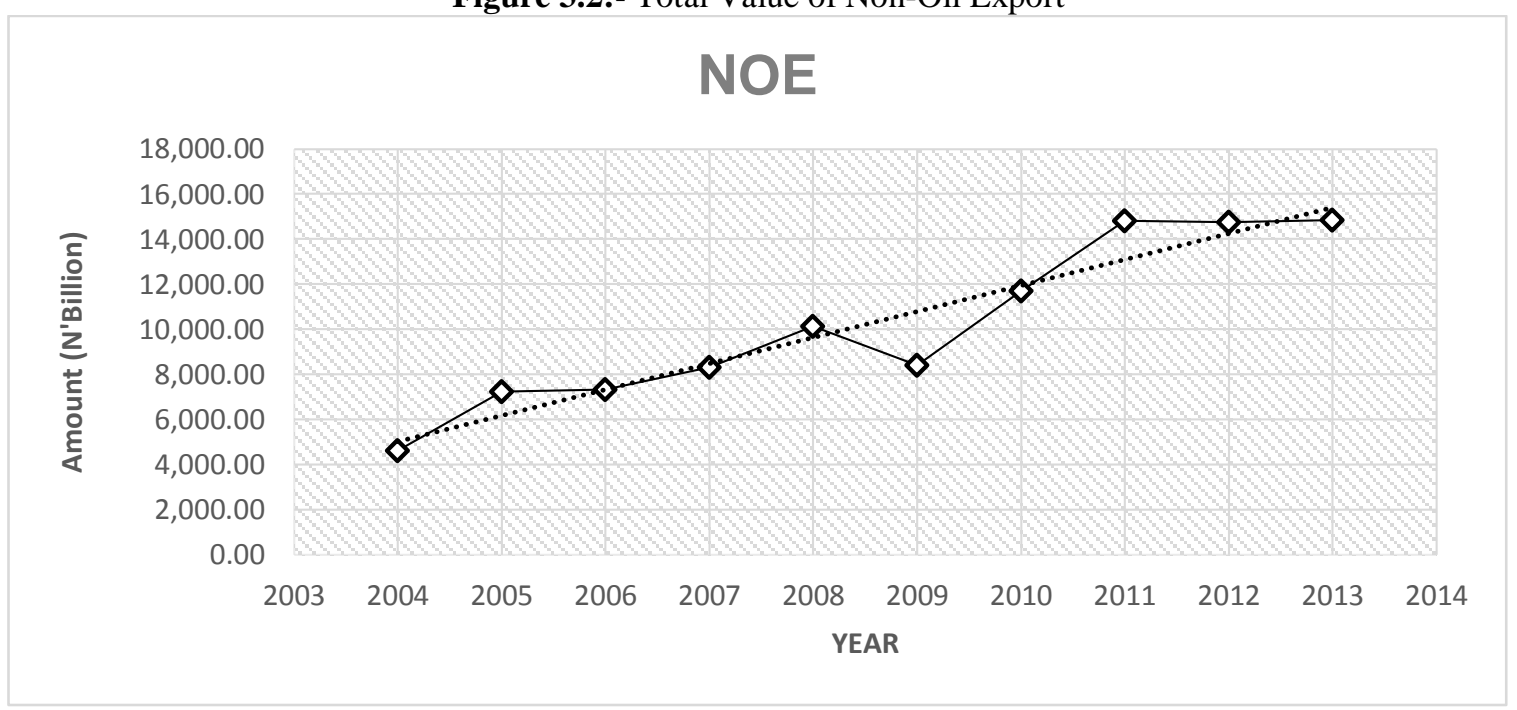

Figure 3.3:- Exchange Rate.

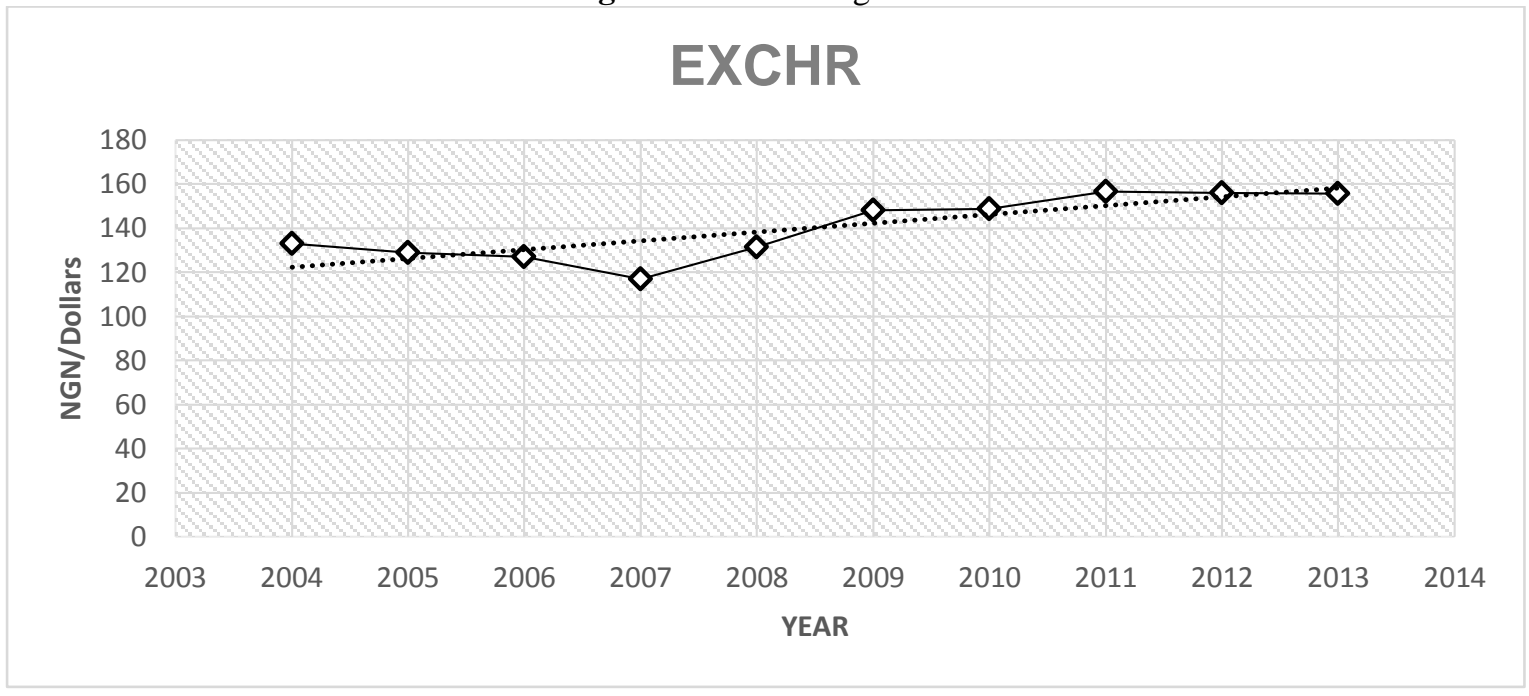

Restatement of Hypotheses in Null and Alternate Forms:-

1. $\mathrm{H}_{0}$ : Non-oil exports have no positive significant impact on economic growth of Nigeria.

2. $\mathrm{H}_{1}$ : Non-oil exports have positive significant impact on economic growth of Nigeria.

3. $\mathrm{H}_{0}$ : Non-oil exports have no positive and significant impact on the value of Nigerian currency.

4. $\mathrm{H}_{1}$ : Non-oil exports have positive and significant impact on the value of Nigerian currency.

Data Analysis:-

Decision Rule: Reject $\mathbf{H}_{0}$ if, p-value $\leq .05$; otherwise accept $\mathbf{H}_{0}$

Two-stage Least Squares Analysis/Ordinary Least Squares Analysis using Statistical Package for Social Sciences (SPSS)

First Model: GDP $=b_{0}+b_{1} \mathrm{NOE}+\mu$

Table 3.2.1:- Model Summary.

\begin{tabular}{|c|c|c|}
\hline \multirow{3}{*}{ Equation 1 } & Multiple R & .956 \\
\cline { 2 - 3 } & R Square & .913 \\
\cline { 2 - 3 } & Adjusted R Square & .902 \\
\cline { 2 - 3 } & Std. Error of the Estimate & 8124.670 \\
\hline
\end{tabular}


Table 3.2.2:- ANOVA

\begin{tabular}{|c|c|c|c|c|c|c|}
\hline \multicolumn{2}{|c|}{} & Sum of Squares & Df & Mean Square & F & Sig. \\
\hline \multirow{3}{*}{ Equation 1 } & Regression & 5550243683.827 & 1 & 5550243683.827 & 84.082 & .000 \\
\cline { 2 - 8 } & Residual & 528082151.427 & 8 & 66010268.928 & & \\
\cline { 2 - 8 } & Total & 6078325835.254 & 9 & & & \\
\hline
\end{tabular}

Table 3.2.3:- Coefficients

\begin{tabular}{|l|l|r|r|r|r|r|}
\hline \multicolumn{2}{|c|}{} & \multicolumn{2}{|c|}{ Unstandardized Coefficients } & \multirow{2}{*}{ Beta } & \multirow{2}{*}{ Sig. } \\
\cline { 3 - 7 } \multicolumn{2}{|c|}{} & B & Std. Error & & & \\
\hline \multirow{2}{*}{ Equation 1 } & (Constant) & -30867.464 & 7970.810 & & -3.873 & .005 \\
\cline { 2 - 8 } & NOE & 6.776 & .739 & .956 & 9.170 & .000 \\
\hline
\end{tabular}

The R of .956 shows that the relationship between the explanatory variable (NOE) and the dependent variable (Gross Domestic Product) is positively strong as the $\mathrm{R}$ is very close to 1 . The $\mathrm{R}^{2}$ of .913 shows that $91.3 \%$ of the variation in RGDP can be explained by NOE. The Anova table shows that the model fit is very significant ( $\mathrm{p}-$ value<.001) thus valid for prediction. The intercept of -30867.464 shows the value of the GDP when NOE is constant. The slope of 6.776 shows that at every unit increase in NOE, Gross Domestic Product will increase by 6.776 units. The independent variable (NOE) is very significant (p-value<.001) in explaining the variation in GDP. After replacing the intercept, the slope and the standard error from the above regression output, we will have GDP = $-30867.464+6.776 \mathrm{NOE}+8124.670$.

\section{Decision:-}

Hypothesis I:-

Non-oil exports have no positive significant impact on economic growth of Nigeria.

The P-value on which basis we can reject the null hypothesis that non-oil exports have no positive significant impact on economic growth of Nigeria is p-value <.001. Since the P-value<.05, we conclude that non-oil exports have positive significant impact on economic growth of Nigeria.

SECOND MODEL: $\quad$ EXCHR $=b_{0}+b_{1} \mathrm{NOE}+\mu$

Table 4.2.4:- Model Summary.

\begin{tabular}{|c|c|c|}
\hline \multirow{3}{*}{ Equation 1 } & Multiple R & .788 \\
\cline { 2 - 3 } & R Square & .621 \\
\cline { 2 - 3 } & Adjusted R Square & .574 \\
\cline { 2 - 3 } & Std. Error of the Estimate & 9.431 \\
\hline
\end{tabular}

Table 4.2.5:- ANOVA

\begin{tabular}{|l|l|r|r|r|r|r|}
\hline \multicolumn{2}{|c|}{} & Sum of Squares & df & Mean Square & F & Sig. \\
\hline \multirow{3}{*}{ Equation 1 } & Regression & 1167.209 & 1 & 1167.209 & 13.124 & .007 \\
\cline { 2 - 7 } & Residual & 711.523 & 8 & 88.940 & & \\
\cline { 2 - 8 } & Total & 1878.732 & 9 & & & \\
\hline
\end{tabular}

Table 4.2.6:- Coefficients.

\begin{tabular}{|c|c|c|c|c|c|c|}
\hline & \multicolumn{2}{|c|}{ Unstandardized Coefficients } & \multirow[t]{2}{*}{ Beta } & \multirow[t]{2}{*}{$\mathrm{t}$} & \multirow[t]{2}{*}{ Sig. } \\
\hline & & B & Std. Error & & & \\
\hline \multirow[t]{2}{*}{ Equation 1} & (Constant) & 108.488 & 9.252 & & 11.726 & .000 \\
\hline & NOE & .003 & .001 & .788 & 3.623 & .007 \\
\hline
\end{tabular}

The R of .788 shows that the relationship between the explanatory variable (NOE) and the dependent variable (EXCHR) is positively strong as the $\mathrm{R}$ is close to 1 . The $\mathrm{R}^{2}$ of .621 shows that $62.1 \%$ of the variation in EXCHR can be explained by NOE. The Anova table shows that the model fit is very significant $(\mathrm{p}$-value $=.007$ ) thus valid for prediction. The intercept of 108.488 shows the value of the Exchange Rate when NOE is constant. The slope of .003 shows that at every percentage increase in NOE, Exchange Rate will increase by .03 percent. The independent variable $(\mathrm{NOE})$ is very significant $(\mathrm{p}$-value $=.007)$ in explaining the variation in Exchange Rate. After replacing the 
intercept, the slope and the standard error from the above regression output, we will have $\mathrm{EXCHR}=108.488+$ $.003 \mathrm{NOE}+9.431$

\section{Decision:-}

Hypothesis II:-

Non-oil exports have no positive and significant impact on the value of Nigerian currency.

The P-value on which basis we can reject the null hypothesis that non-oil exports have no positive and significant impact on the value of Nigerian currency is .007. Since the P-value<.05, we conclude alternatively that non-oil exports have positive and significant impact on the value of Nigerian currency.

\section{Summary of Findings/Discussion:-}

After subjecting the hypotheses under tests, findings revealed that:-

1. Non-oil exports have positive significant impact on economic growth of Nigeria

2. Non-oil exports have positive and significant impact on the value of Nigerian currency

This paper examined the impact of non-oil exports on the growth of Nigerian economy. Ordinary least square regression analysis was employed in data analysis because of its special feature of minimizing errors in prediction. The researcher however, found that non-oil exports had significant impact on Nigeria's economic growth between 2004 and 2013 and that non-oil exports had positive and significant impact on the value of Nigerian currency within the period under review.

\section{Recommendation/Conclusion:-}

In view of the findings, the following are recommended:-

1. Reducing trade dependence on developed countries by looking for other markets, particularly developing countries so as to enhance development in both countries. Inter-regional trade between Sub-Saharan African countries should also be encouraged because of the relatively low transportation cost and loose importation barriers.

2. The export base of Nigeria should be diversified to favour the non-oil sectors to help reduce sector marginalization. It will also help cushion the effect of price shocks in the international oil (crude oil) market.

3. Mining companies should be persuaded to diversify their interests into other minerals in Nigeria (i.e. the Gold reserve in Kaduna).

4. Formulation of policies that will promote exportation of locally produced goods.

5. Encouragement of production and exportation of value added commodities because of its relatively high price and income elasticities of demand, storability and adaptability over primary products such as processed agricultural products or foods.

6. Direct government intervention through creating a ministry specifically for mineral exploration

If the various recommendations are properly implemented, then the contribution of non-oil exports to GDP is expected to increase to a significant level. It will also help absorb any shocks from the international oil market and Nigeria will be on its way to economic prosperity.

\section{References:-}

1. Edame, G. E. and Efefiom, C. (2013). The trend analysis of oil revenue and oil export in Nigeria. Journal of Business and Management (IOSR-JBM), 10(3), pp. 41-58.

2. Enoma, A. and Isedu, M. (2011). The Impact of Financial Sector Reforms on Non-Oil Export in Nigeria. Journal of Economics, 2 (2), pp. 112-130

3. Ningi, S. I. (2013). An analysis of banks financing of non-oil exports in Nigeria. American International Journal of Contemporary Research, 3(1), pp. 85-92.

4. Olurankinse, F. and Fatukasi, B. (2012). Analysis of the impact of non-oil sector on economic growth, Canadian Social Science, 8(4), pp. 244-248.

5. Onodugo, V. A., Ikpe, M. \& Anowor, O. F. (2013). Non-oil Export and Economic Growth in Nigeria: A Time Series Econometric Model. International Journal of Business Management \& Research, 3 (2), pp. 115-124.

6. Onwualu A. P. (2012). Agricultural sector and national development: focus on value chain approach. 5th Annual lecture, Onitsha chamber of commerce. 
7. Ozurumba, B. A. and Chigbu, E. E. (2013). Non-oil export financing and Nigeria's economic growth. Interdisciplinary Journal of Contemporary Research in Business, 4(10), pp. 133-148

8. Raheem, I. and Busari, A. (2013). Non-oil export and economic growth in Nigeria: does methodology matter? Journal of Asian Development Studies, 2(2), pp. 21-34.

9. Riman, H. B.; Akpan, E. S.; Offiong, A. I., \& Ojong, C. M. (2013). Nexus between oil revenue, non-oil export and industrial output in Nigeria: an application of the VAR model. International Journal of Financial Economics, 1(2), pp. 48-60. 